\title{
A GENETICALLY ENCODED BIOSENSOR ROKATE FOR MONITORING THE REDOX STATE OF THE GLUTATHIONE POOL
}

Shokhina $A^{1}$, Belousov $W^{1,2}$, Bilan DS ${ }^{1}$

Shemyakin-Ovchinnikov Institute of Bioorganic Chemistry, Moscow, Russia

2 Institute of Translatinoal Medicine,

Pirogov Russian National Research Medical University, Moscow, Russia

\begin{abstract}
Genetically encoded fluorescent sensors are exploited to study a variety of biological processes in living organisms in real time. In recent years, a whole family of biosensors has been developed, serving to visualize changes in the glutathione redox state. The aim of our experiment was to design a biosensor based on the red fluorescent protein mKate2 for measuring the 2 GSH/GSSG ratio. A pair of cysteine amino acid residues were introduced into the structure of the fluorescent protein using site-directed mutagenesis. These residues form a disulfide bridge when the surrounding glutathione pool is oxidized, affecting the spectral characteristics of the protein. Our biosensor, which we called roKate, was tested in vitro on an isolated protein. Specifically, we examined the spectral characteristics, pH and the redox potential of the sensor. Additionally, the performance of roKate was evaluated using the culture of living mammalian cells. The fluorescent signal emitted by the sensor was very bright and remarkably stable under $\mathrm{pH}$ conditions varying in the physiological range. Irreversibly oxidized in mammalian cells, roKate stands out from other members of this biosensor family. This biosensor should be preferred in the experiments when the time between the manipulations with the biological object and the subsequent analysis of the induced effect is substantial, as is the case with long sample preparation.
\end{abstract}

Keywords: genetically encoded fluorescent sensor, glutathione, 2GSH/GSSG ratio, roKate

Funding: this work was supported by the Russian Foundation for Basic Research (Project mol_a_dk No.16-34-60175).

Author contribution: Shokhina AG was responsible for the experimental part of the study. Belousov W and Bilan DS supervised the study and prepared this manuscript.

$\triangle$ Correspondence should be addressed: Dmitry S. Bilan

Miklouho-Maclay, 16/10, Moscow, 117997; d.s.bilan@gmail.com

Received: 26.12.2018 Accepted: 02.03.2019 Published online: 14.03.2019

DOI: $10.24075 /$ brsmu.2019.013

\section{ГЕНЕТИЧЕСКИ КОДИРУЕМЫЙ БИОСЕНСОР ROКАТЕ ДЛЯ РЕГИСТРАЦИИ РЕДОКС-СОСТОЯНИЯ ПУЛА ГЛУТАТИОНА}

А. Г. Шохина', В. В. Белоусов ${ }^{1,2}$, Д. С. Билан ${ }^{1 凶}$

${ }^{1}$ Институт биоорганической химии имени М. М. Шемякина и Ю. А. Овчинникова РАН, Москва, Россия

2 Научно-исследовательский институт трансляционной медицины,

Российский национальный исследовательский медицинский университет имени Н. И. Пирогова, Москва, Россия

Генетически кодируемые биосенсоры на основе флуоресцентных белков представляют собой инструмент исследования ряда биологических процессов в живых системах в режиме реального времени. За последние годы было создано целое семейство биосенсоров, позволяющих визуализировать в живых клетках изменения редокс-состояния пула глутатиона. Целью настоящей работы была разработка нового биосенсора для регистрации соотношения 2GSH/GSSG на основе красного флуоресцентного белка mКаte2. Для этого методом направленного мутагенеза в структуру флуоресцентного белка вносили пару аминокислотных остатков цистеина, которые при окислении окружающего пула глутатиона формируют дисульфидную связь, что приводит к изменению спектральных характеристик. Полученный биосенсор был протестирован in vitro на выделенном препарате белка, в частности, были исследованы спектральные характеристики, рН-чувствительность белка, окислительно-восстановительный потенциал. Кроме того, биосенсор, названный roKate, был протестирован в культуре живых клеток млекопитающих. Он отличается высокой яркостью и повышенной стабильностью сигнала при изменениях рН в физиологическом диапазоне. От других представителей данного семейства биосенсоров гоКате отличается необратимым изменением сигнала при окислении в клетках млекопитающих. Применение данного сенсора предпочтительно в экспериментах с наличием длительного промежутка времени между воздействием на биологическую систему и последующим анализом вызванного эффекта, например в условиях длительной пробоподготовки.

Ключевые слова: генетически кодируемый флуоресцентный биосенсор, глутатион, соотношение 2GSH/GSSG, roKate

Финансирование: работа выполнена при поддержке гранта РФФИ мол_а_дк № 16-34-60175.

Информация о вкладе авторов: А. Г. Шохина проводила экспериментальную работу; В. В. Белоусов и Д. С. Билан руководили исследованиями, писали текст статьи.

$\bowtie$ Для корреспонденции: Дмитрий Сергеевич Билан

ул. Миклухо-Маклая, д. 16/10, г. Москва, 117997; d.s.bilan@gmail.com

Статья получена: 26.12.2018 Статья принята к печати: 02.03.2019 Опубликована онлайн: 14.03.2019

DOI: $10.24075 /$ vrgmu.2019.013

Research into redox reactions is a burgeoning field of contemporary biomedicine. The ratio of reduced (GSH) to oxidized (GSSG) glutathione is an important characteristic of a cell's redox state. Essentially, glutathione is an abundant tripeptide ( $y$-L-glutamyl-L-cysteinyl-glycine), whose intracellular concentrations can be as high as $10 \mathrm{mM}$ [1]. The biological function of glutathione relies on the ability of its two reduced molecules (2GSH) to pass on a pair of electrons to an acceptor molecule. During this process, glutathione is oxidized to a disulfide form that can be further converted back to GSH by glutathione reductase (GR) [2]. GSH plays a key role in the reduction of oxidative stress products, including lipid and hydrogen peroxides. Glutathione reduces reversible disulfide bonds that largely determine the structure and function of many cellular proteins [3]. Summing up, firstly, glutathione is a critical component of the thiol-disulfide exchange and secondly, it is involved in protein glutathionylation, playing a crucial role in intracellular redox signaling and protein folding. 
Defects in the regulatory systems controlling the intracellular levels of glutathione or its redox homeostasis (the 2GSH/ GSSG ratio) can promote pathology. Impaired glutathione synthesis caused by mutations in the genes coding for the subunits of $y$ - glutamyl-cysteine-synthase is linked to diabetes mellitus [4], asthma [5], schizophrenia [6], and other diseases. Deficient activity of glutathione reductase that maintains the GSH pool is associated with systemic lupus erythematosus [7] and some forms of favism [8]. By contrast, in cancer cells this enzyme is often hyperactive, causing an increase in GSH concentrations and strengthening the antioxidant defense of malignant cells [9]. Changes in the 2GSH/GSSG ratio that characterizes the redox state of the intracellular environment can indicate both pathological and normal physiological processes, such as differentiation [10, 11], proliferation [12], or apoptosis [13]. However, if these changes are massive and uncontrolled, they can cause a wide range of disorders, including neurodegenerative, immune, cardiovascular, etc. [14]. Among other functions of glutathione in the living organism is participation in the metabolism of xenobiotics that includes conjugation to GSH in the reaction catalyzed by glutathione transferases [15].

In a biological sample, GSH and GSSG can be measured by high-performance liquid chromatography (HPLC). Another approach to investigating the redox state of the glutathione pool involves the use of chemical dyes. Prior to staining with the classic Ellman's reagent [16], cells need to be lysed or tissue homogenate needs to be prepared. By contrast, synthetic dyes like ThiolQuant Green [17] and RealThiol [18] can be used in intact cells; however, they provide information about GSH concentrations only. At present, genetically encoded sensors based on redox-sensitive fluorescent proteins (roFP) have become very popular as tools for monitoring the dynamics of the GSH redox ratio. Such sensors rely on the oxidation of two surface cysteine residues incorporated into the structure of a fluorescent protein by site-directed mutagenesis. The oxidation degree of the redox-sensitive cysteine residues is determined by the surrounding glutathione pool. Being in close proximity to each other, the cysteine residues form a disulfide bond when oxidized in response to change in the GSH redox ratio. This leads to conformational rearrangements affecting the spectral characteristics of the fluorescent protein. Depending on the 2GSH/GSSG value, roFP can be either in reduced or oxidized forms distinguished by their spectra. Because such biosensors are protein-based, they can be expressed in a wide range of biological system, from individual cell organelles to transgenic organism tissue. The history of this biosensor family started with a yellow fluorescent protein [19]; green protein sensors appeared shortly afterwards [20, 21]. Today, we have an arsenal of diverse redox-sensitive sensors at our disposal that can be employed to monitor the 2GSH/GSSG dynamics in living systems in real time. They vary in their spectral characteristics, redox potential, reaction rate, and specificity [22].

The most convenient fluorescent sensors for in vivo experiments are those emitting in the far-red spectrum [23]; over this wavelength range, light absorption by water, hemoglobin, melanin and other tissue compounds is minimal. Besides, the green light used to excite a chromophore of a red protein is less toxic for cells in comparison with blue and violet used to induce fluorescence of green biosensors. The aim of this study was to create a new version of a redox biosensor based on the mKate2 red fluorescent protein. The sensor that we called roKate exhibits increased $\mathrm{pH}$ stability and brightness. The distinctive feature of the roKate biosensor is its irreversible response in mammalian cells upon oxidation, which allows researchers to use it as a sensor that has an "oxidation memory" of glutathione pool oxidation.

\section{METHODS}

\section{Genetic constructs}

Point mutations were introduced into the structure of the red fluorescent protein mKate2. The sample for DNA amplification contained thermally stable Tersus polymerase in a buffer (Evrogen; Russia) and an equimolar mixture of dNTP (200 $\mu \mathrm{M})$, primers $(10 \mu \mathrm{M})$ and a DNA template (100 ng). The PCR protocol included 22 cycles of denaturation $\left(95^{\circ} \mathrm{C}, 30 \mathrm{~s}\right)$, annealing $\left(60^{\circ} \mathrm{C}, 45 \mathrm{~s}\right)$ and elongation $\left(72^{\circ} \mathrm{C}, 90 \mathrm{~s}\right)$.

Random mutagenesis was performed to improve the properties of the genetic constructs. The reaction mix contained thermally stable Taq polymerase in a buffer (Evrogen; Russia), primers $(10 \mu \mathrm{M})$, dATP $(200 \mu \mathrm{M})$, dTTP $(200 \mu \mathrm{M})$, dCTP $(200 \mu \mathrm{M})$, dGTP $(360 \mu \mathrm{M})$, MnSO4 (640 $\mu \mathrm{M})$, and a DNA template (20 pg). The PCR protocol included 27 cycles of denaturation $\left(95^{\circ} \mathrm{C}\right.$, $30 \mathrm{~s})$, annealing $\left(60^{\circ} \mathrm{C}, 45 \mathrm{~s}\right)$ and elongation $\left(72^{\circ} \mathrm{C}, 105 \mathrm{~s}\right)$. The expected number of mutations was $4-5$ per construct [24]. The obtained samples were cloned into plasmid vectors: pQe30 (to facilitate expression in bacterial cells) and pC1 (to facilitate expression in mammalian cells).

\section{Bacterial cells}

We used strain XL1-Blue of E. coli. The cells were cultured in an LB broth or in a solid medium in Petri dishes (1.5\% LB agar). The medium contained $100 \mu \mathrm{kg} / \mathrm{ml}$ ampicillin (for $\mathrm{pQe30}$ ) or $25 \mu \mathrm{kg} / \mathrm{ml}$ kanamycin (for pC1).

The US SZX12 fluorescence microscope (Olympus; Japan) was used to select the brightest fluorescent colonies that were subsequently transferred onto the solid substrate. Further measurements were carried out usingVarian Cary Eclipse fluorescence spectrophotometer (Agilent; USA). Briefly, the bacterial biomass was suspended in $1 \mathrm{ml}$ of PBS and fluorescence emission and excitation spectra were recorded at $\lambda e x=585 \mathrm{~nm}$ and $\lambda e m=624 \mathrm{~nm}$, respectively. To change the redox state of the cells, $\mathrm{H}_{2} \mathrm{O}_{2}$ was added to the suspension at the final concentrations of $100 \mu \mathrm{M}-2 \mathrm{mM}$. The data were processed in OriginPro 9.0 (OriginLab; USA).

\section{The recombinant protein}

XL1-Blue E. coli cells were transformed with the roKate pQe30 plasmid. The mKate2 protein expressed by the cells had a histidine tag (His-tag) at its C-terminus. The bacterial clones were cultured in LB broth containing $100 \mu \mathrm{kg} / \mathrm{ml}$ ampicillin for $16 \mathrm{~h}$ at room temperature under continuous stirring at $200 \mathrm{rpm}$. The obtained bacterial suspension was pelleted by centrifugation for $15 \mathrm{~min}$ at 2,000 $\mathrm{g}$ and $4{ }^{\circ} \mathrm{C}$. Cell lysis was aided by the commercial B-PER ${ }^{\mathrm{TM}}$ Bacterial Protein Extraction Reagent (ThermoFisher; USA). Then, the samples were again centrifuged for $20 \mathrm{~min}$ at $18,000 \mathrm{~g}$ and $4{ }^{\circ} \mathrm{C}$. The supernatant was applied to the chromatography column containing TALON purification resin (Clontech; USA) capable of binding to the His-tag. The protein was eluted from the column using a PBS solution ( $\mathrm{pH}$ 7.0) containing $250 \mathrm{mM}$ imidazole. To separate imidazole from the recombinant protein, the latter was run through a gel filtration column packed with Sephadex G-50 (GE Healthcare Life Sciences; UK). The sample was incubated in a PBS solution containing $20 \mathrm{mM}$ dithiothreitol for $30 \mathrm{~min}$ to reduce disulfide bonds. 


\section{In vitro tests of the biosensor}

An aliquot of the purified protein was added to $1 \mathrm{ml}$ of PBS $(\mathrm{pH}$ 7.0) at a final concentration of $100 \mathrm{nM}$ in a spectrophotometry cuvette. Fluorescence emission and excitation spectra were recorded by Varian Cary Eclipse (Agilent; USA) at $\lambda e x=585 \mathrm{~nm}$ and $\lambda e m=624 \mathrm{~nm}$. GSSG or GSH were added to the sample at concentrations ranging between $50 \mu \mathrm{M}$ and $2 \mathrm{mMl}$; the spectra were recorded subsequently.

The purified protein was titrated with glutathione solutions with the GSH/GSSG ratio varying from $10: 0$ to $0: 10$. Then, the following approach was applied to measure the redox potential of the tested biosensor. First, $Y$ was calculated by the formula: $Y=\left(F_{n}-F_{\min }\right) /\left(F_{\max }-F_{n}\right)$, where $F_{n}$ is fluorescence intensity in the sample with a known GSH/GSSG value; $F_{\min }$ is fluorescence intensity in the sample containing $1 \mathrm{mM}$ GSSG; $F_{\max }$ is fluorescence intensity in the sample containing $1 \mathrm{mM}$ GSH. Then, logY was plotted against $\log ([\mathrm{GSSG}] /[\mathrm{GSH}])$. A GSSG/2GSH ratio was determined at which the signal intensity changed by $50 \%$; the obtained value was designated as $\mathrm{A}$. The equilibrium constant $\mathrm{K}_{\mathrm{eq}}$ was calculated by the formula: $\log \mathrm{K}_{\mathrm{eq}}=$ $\log \left(F_{\max } / F_{\text {min }}\right)-\log A$. The redox potential $(E)$ was calculated by the formula: $\mathrm{E}=\mathrm{E}_{0}-(\mathrm{RT} / \mathrm{nF}) \cdot \mathrm{nK} \mathrm{K}_{\text {eq }}$, where $\mathrm{E}_{0}$ is the redox potential of glutathione $(-240 \mathrm{mV})$ at $\mathrm{pH}=7.0 ; \mathrm{R}$ is the gas constant $(8.314 \mathrm{~J} / \mathrm{mol} \cdot \mathrm{K}) ; \mathrm{T}$ is temperature $(\mathrm{K}) ; n$ is the number of electrons participating in the exchange; $F$ is the Faraday constant (96, $490 \mathrm{~J} / \mathrm{mol} / \mathrm{N})$.

For samples with a known GSH:GSSG ratio, the oxidation degrees $(\mathrm{O} x \mathrm{D})$ of the glutathione pool and roKate were calculated by the following formulas:

$$
\begin{aligned}
& \mathrm{OxD}_{\mathrm{GSH}}=2[\mathrm{GSH}] /(2[\mathrm{GSSG}]+[\mathrm{GSH}]) \\
& \mathrm{OxD}_{\text {roKate }}=[\mathrm{GSH}] /\left([\mathrm{GSSG}]\left(\mathrm{K}_{\text {eq }}+[\mathrm{GSH}] /[\mathrm{GSSG}]\right)\right) .
\end{aligned}
$$

The quantum yield of the biosensor was calculated by the formula: $Q Y=\left(\left(E_{\text {rokate }} \cdot \mathrm{Abs}_{\text {mKate2 }}\right) /\left(\mathrm{Em}_{\text {mKate2 }} \cdot \mathrm{Abs}_{\text {rokate }}\right)\right) \cdot$ QY ${ }_{\text {mKate2, where }} \mathrm{Em}_{\text {rokate }}$ and $E \mathrm{~m}_{\text {mKate2 }}$ are intensities of the fluorescent signals emitted by roKate and the reference mKate2 protein with the emission peak at $\lambda=624 \mathrm{~nm}$; Abs $_{\text {rokate }}$ and $\mathrm{Abs}_{\text {mKate2 }}$ are absorbances of roKate and the reference mKate2 protein at $\lambda=590 \mathrm{~nm}$; $Q Y_{\text {Kkate } 2}$ is the quantum yield of mKate2 (a precalculated value, 0.4 ).

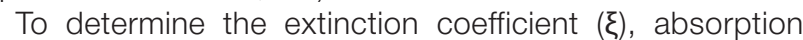
spectra were recorded at $\lambda=590 \mathrm{~nm}$ for native roKate and roKate denatured in $1 \mathrm{mM} \mathrm{NaOH}$. Following the assumption that $\xi$ of the denatured roKate chromophore equals $\xi$ of mKate2 $\left(62,500 \mathrm{M}^{-1} \cdot \mathrm{cm}^{-1}\right)$, we calculated the extinction coefficient for the native protein by the formula: $\xi_{\text {native }}=\left(\mathrm{Abs}_{\text {native }} \cdot \xi_{\text {denat }}\right) /$ $\mathrm{Abs}_{\text {den }}$

$\mathrm{pK}_{\mathrm{a}}$ of the biosensor was measured using a series of buffer solutions with a known $\mathrm{pH}$ ranging from 3.0 to 11.0 (at 0.5 increments). An aliquot of the protein was added to each of the solutions at a final concentration of $100 \mathrm{nM}$ and the fluorescence excitation spectrum was recorded; then, the fluorescence intensity/pH curve was built.

\section{Mammalian cell culture}

In our experiment, we used the HeLa Kyoto cell line cultured in DMEM supplemented with 10\% FBS, 2 mM glutamine, $1 \%$ of penicillin and streptomycin. The cells were grown at $37^{\circ} \mathrm{C}$ in a $5 \% \mathrm{CO}_{2}$ atmosphere.

Prior to transfection, the cells were plated and cultured in 35 mm glass-bottom microscopy dishes FluoroDishes (World Precision Instruments; USA). Plasmid DNA was mixed with the
FuGene HD transfection reagent (Promega; USA) following the manufacturer's protocol. After the transfection solution was added to the cell culture, the dishes were put in the incubator. Microscopy was performed on the following day.

\section{Fluorescent microscopy}

Microscopy was performed using the DMI 6000 B microscope (Leica; Germany) equipped with a 120W HXP mercury lamp (Osram; Germany) and a CoolSNAP HQ CCD-camera (Photometrics; USA). The TX2 filter (Excitation: BP560/40; Emission: BP645/75) was used to record fluorescence in the far-red spectrum. Prior to microscopy, the DMEM medium was replaced with a Hanks' balanced salt solution containing $15 \mathrm{mM}$ Hepes. Microscopy was performed in $1 \mathrm{ml}$ of the medium at $37{ }^{\circ} \mathrm{C}$. One hundred $\mu \mathrm{L}$ of hydrogen peroxide brought to a final concentration of $750 \mu \mathrm{M}$ was added to the cells in order to oxidize the intracellular glutathione pool. Dithiothreitol taken at a final concentration of $2 \mathrm{mM}$ was used as a reductant. The images were analyzed in Leica Application Suite Advanced Fluorescence software (Leica; Germany). Final image processing was done in ImageJ (EMBL; Germany) and OriginPro 9.0 (OriginLab; USA).

\section{RESULTS}

\section{Genetic constructs}

The red fluorescent protein mKate2 is a monomer that produces very bright fluorescence and is stable under physiological $\mathrm{pH}$ conditions [23]. So, we selected this protein to design a redox biosensor capable of reporting shifts in the 2 GSH/GSSG ratio. A pair of cysteine (Cys) residues was introduced into the protein structure by site-directed mutagenesis in such way that they could form a disulfide bond when oxidized. In total, 10 protein variants were obtained differing in the positions of Cys insertions: 142/198, 142/196, 141/161, 144/196, 141/198, $141 / 161,141 / 196,107 / 118,140 / 214$, and $200 / 214$. It is known that it takes quite a time for the equilibrium between the redox-active cysteine residues of previously designed rxYFP and roGFP biosensors and the glutathione pool to settle. However, if glutaredoxin ( $\mathrm{rr}$ ) concentrations are increased in the vicinity of these proteins, the reaction accelerates. Therefore, rxYFP and roGFP were fused to human Grx1 at the gene level via a polypeptide linker $[25,26]$ to speed up the reaction. All mKate2-based constructs contained human Grx1 attached by a linker (Gly-Gly-Ser-Gly-Gly)6 to their N-terminus. Fig. $1 \mathrm{~A}$ is a schematic representation of how the obtained biosensor is expected to function.

\section{roKate expression in bacterial cells}

The obtained genetic constructs were expressed in XL1 Blue E. coli bacterial cells. Twenty-four hours later, fluorescence intensity was measured in the grown colonies. To assess the functional activity of each fluorescent biosensor variant, we recorded changes in the fluorescence excitation spectra before and after $\mathrm{H}_{2} \mathrm{O}_{2}$ (the final concentration of $1 \mathrm{mM}$ ) was added to the bacterial suspension. $\mathrm{H}_{2} \mathrm{O}_{2}$ is a powerful oxidant that significantly affects the redox state of the intracellular environment if taken in excess. It also leads to the increased production of GSSG. Grx1-mKate2 was used as a negative control. This protein does not contain redox-active Cys in the chromophore environment of the fluorescent protein and, therefore, does not respond to oxidation by changing 
its spectral properties. After the measurements, two proteins with Cys at positions 141/198 and 141/196 were selected for further experiments. Other mutants either lacked fluorescent properties or were insensitive to oxidation.

Fluorescence intensity of the selected mutants declined by less than $10 \%$ in response to oxidation with $\mathrm{H}_{2} \mathrm{O}_{2}$. Random mutagenesis was performed to improve the properties of the proteins. This method produces a fixed number of random mutations in a targeted gene and can be used to obtain thousands of variants of the same protein that differ in only a few amino acid substitutions. Since even a single mutation can significantly affect the properties of a protein, further screening should be performed to identify the optimal mutants. After running a few cycles of random mutagenesis, we selected the brightest clones that were further tested under the conditions of oxidative stress. Finally, we opted for a mutant that contained redox-active Cys141 and Cys198 and additional mutations Lys12Glu and Asn21Asp in the structure of the fluorescent protein. This mutant protein was named roKate. It responded to oxidation by at least a $40 \%$ drop in fluorescence intensity.

\section{Measuring roKate characteristics in vitro}

The roKate protein was purified for further in-depth analysis. This protein has one fluorescence excitation peak at $585 \mathrm{~nm}$ and one emission peak at $624 \mathrm{~nm}$ (Fig. 1B). Because during the initial screening $\mathrm{H}_{2} \mathrm{O}_{2}$ concentrations were high, the first thing to test was whether $\mathrm{H}_{2} \mathrm{O}_{2}$ could directly oxidize the redoxactive Cys residues of the protein. $\mathrm{H}_{2} \mathrm{O}_{2}$ at a final concentration of $1 \mathrm{mM}$ was added to the protein sample (100 nM), causing no changes to the excitation spectra of the sample (Fig. 1C). However, fluorescence intensity dropped by $40 \%$ when $1 \mathrm{mM}$ of $\mathrm{GSH}$ was added to the sample before $1 \mathrm{mM}$ of $\mathrm{H}_{2} \mathrm{O}_{2}$ was added, which can be explained by GSH oxidation (Fig. 1D). The same fluorescence pattern was observed when pre-oxidized GSSG (1 mM) was added to the protein sample (Fig. 1E). That reaction was reversible in vitro. If glutathione reductase (GR) and NADPH were introduced into the same sample, fluorescence intensity went back to its initial value (Fig. 1E). Thus, changes in the signal intensity were mediated by the changes in the glutathione redox state.
A

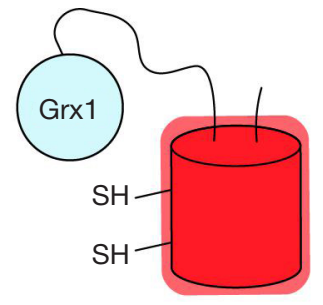

B

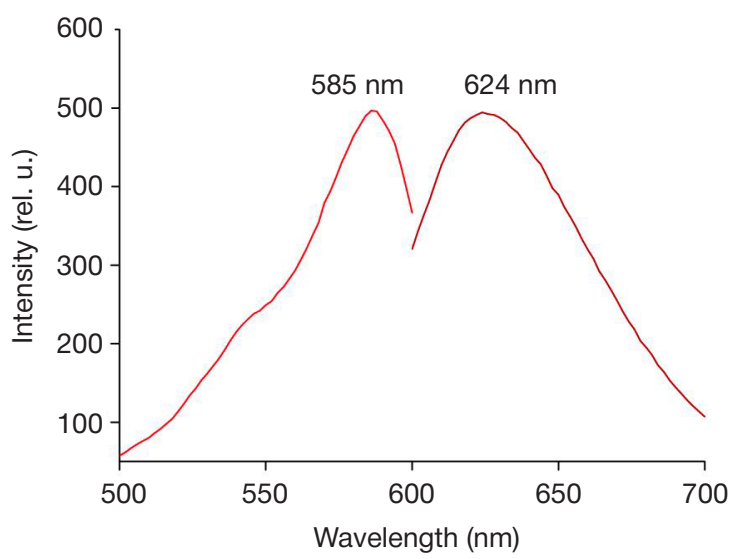

D

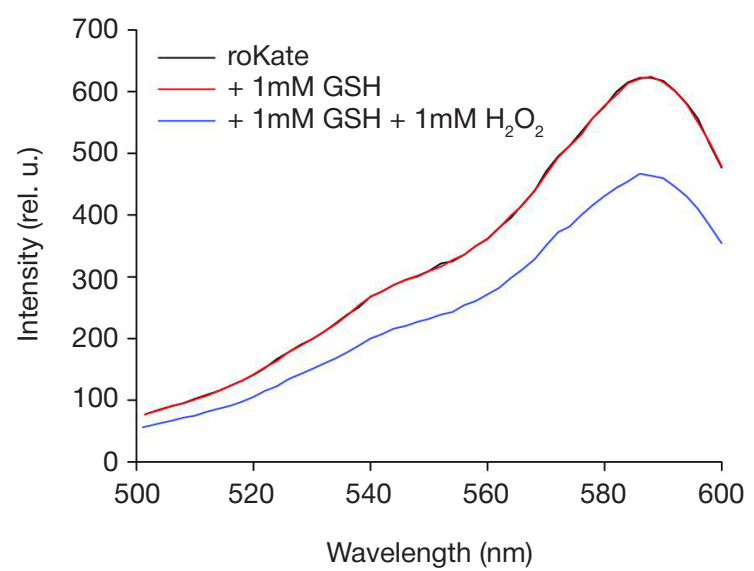

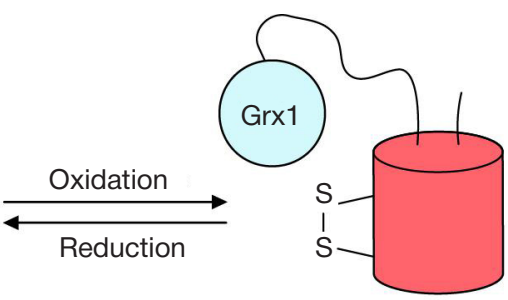

C

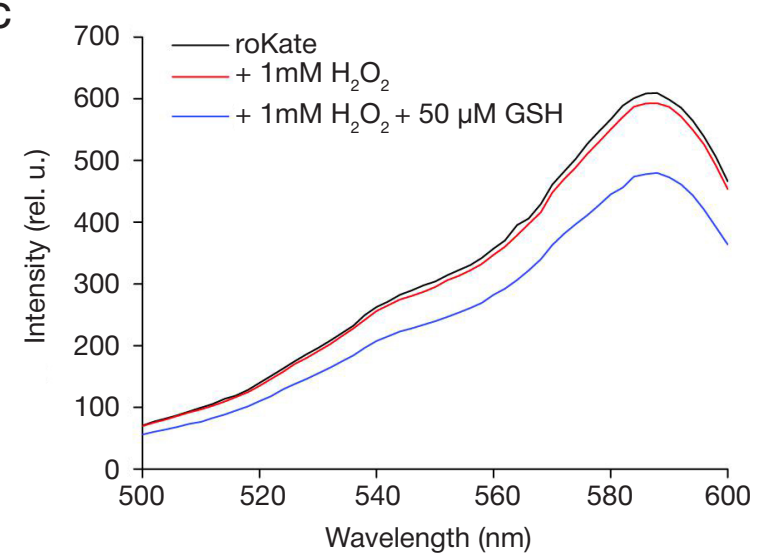

E

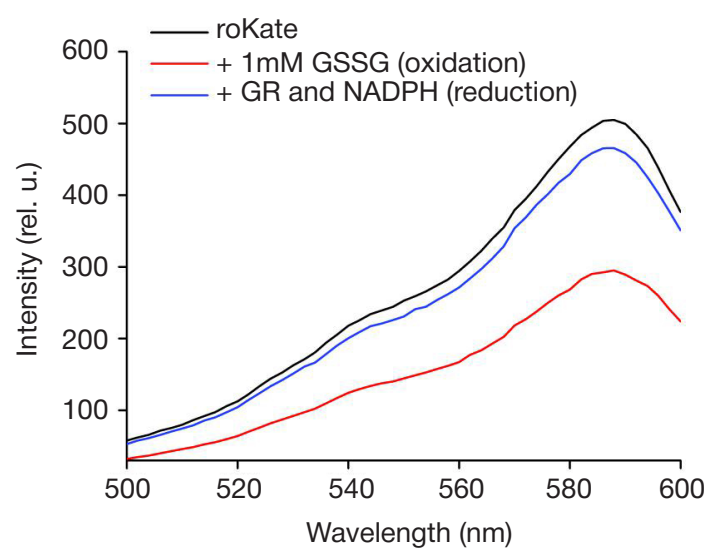

Fig. 1. A. A schematic representation of roKate's functioning. Two closely positioned cysteine amino acid residues were incorporated into the protein's structure. When oxidized, the residues form a disulfide bond in the presence of human glutaredoxin 1 (Grx1). Oxidation is accompanied by a drop in fluorescence intensity. B. The fluorescence emission and excitation spectra of the biosensor. C. Changes in the fluorescence excitation spectra in response to the presence of hydrogen peroxide and the subsequent addition of GSH. D. Changes in the fluorescence excitation spectra in response to the presence of GSH and the subsequent addition of hydrogen peroxide. E. Changes in the fluorescence excitation spectra in the isolated protein sample accompanying oxidation (the addition of GSSG) and subsequent reduction (enzymatic reaction of glutathione reduction in the presence of GR and NADPH) 
A

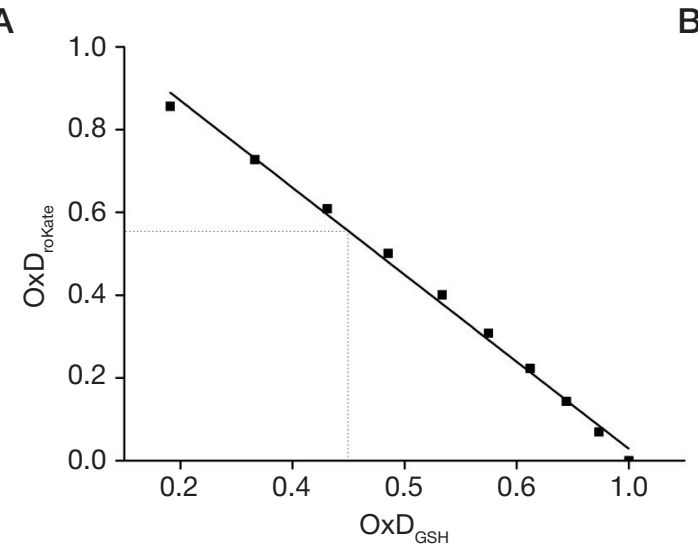

B

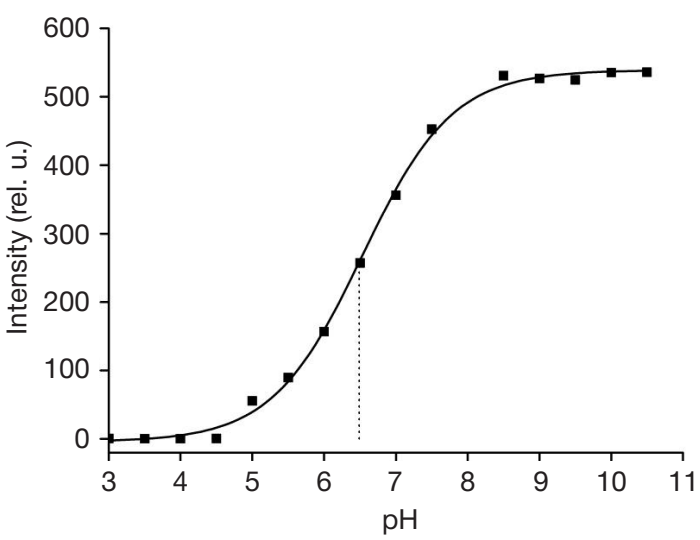

Fig. 2. A. Relationship between roKate and glutathione oxidation degrees. B. Relationship between roKate's fluorescence intensity and pH

A

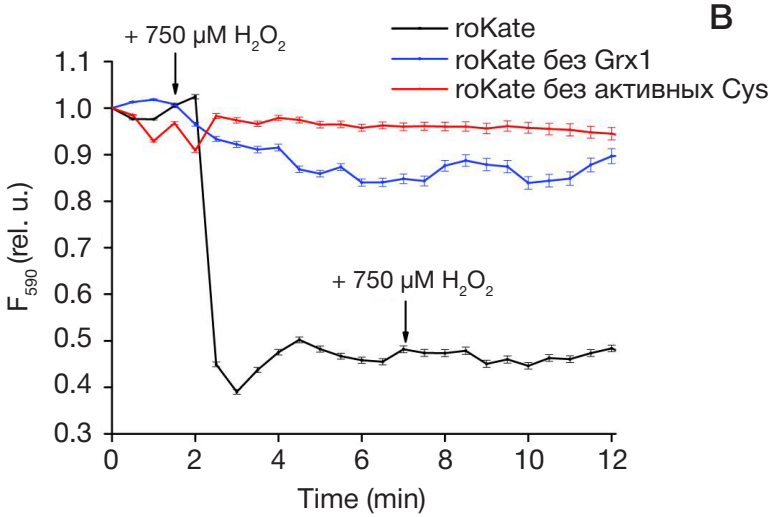

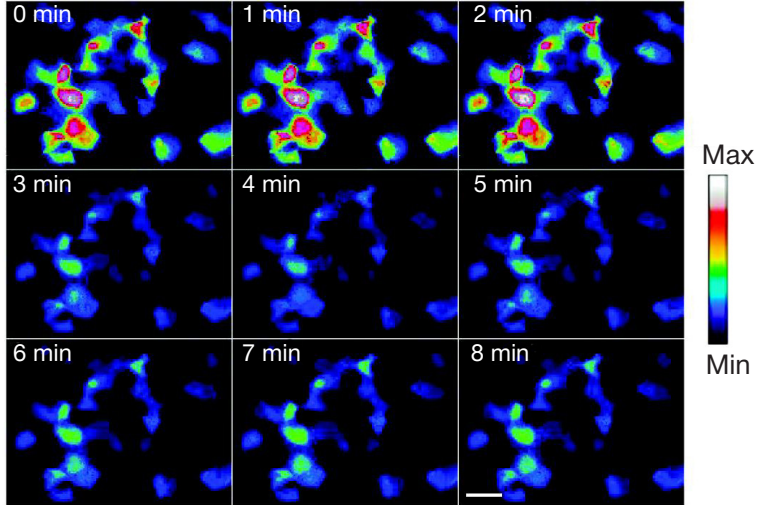

Fig. 3. The roKate biosensor in HeLa Kyoto cells. A. Fluorescence intensity dynamics of roKate (the black curve), its variant without Grx1 (the blue curve) and its variant without redox-active cysteine residues (the red curve) in the cytoplasm of living HeLa Kyoto cells in response to the addition of hydrogen peroxide to the medium (the moment hydrogen peroxide was added is marked by an arrow). Error bars show the standard deviation from the mean. B. Images of HeLa Kyoto cells expressing the roKate biosensor before and after the addition of hydrogen peroxide (the time on the images corresponds to that on the graph). The images are shown in pseudo colors corresponding to signal intensity. Scale: $40 \mu \mathrm{m}$

The purified roKate protein was titrated with solutions with different GSH /GSSG ratios ranging from $10: 0$ to $0: 10$. This was necessary to evaluate roKate's redox potential. Fig. 2A shows the relationship between roKate and glutathione oxidation degrees. The redox potential of the biosensorwas $-245 \mathrm{mV}$.

The $\mathrm{pH}$ sensitivity of the protein was tested using a standard series of buffer solutions with a known $\mathrm{pH}$. The chromophore of fluorescent proteins can exist in a protonated or deprotonated state due to the presence of an amino acid tyrosine residue in its structure. Therefore, the intensity of the fluorescent signal depends on $\mathrm{pH}$. In an experimental system, it is important to keep in mind that the amplitude of changes that the fluorescent signal undergoes under different $\mathrm{pH}$ conditions varying in the physiological range (6.0-8.0). We found that $\mathrm{pK}_{\mathrm{a}}$ of the roKate biosensor was 6.5. As pH went up from 6.0 to 8.0, fluorescence increased threefold (Fig. 2B).

We also calculated the extinction coefficient and the quantum yield of roKate. They were $36,400 \mathrm{M}^{-1} \mathrm{~cm}^{-1}$ and 0.3 , respectively.

\section{roKate expression in eukaryotic cells}

The roKate gene was cloned into the $\mathrm{pC} 1$ vector for further expression in mammalian cells. For the human HeLa Kyoto cell line, the maximum amplitude of the response was 55\% under the conditions of oxidative stress caused by $\mathrm{H}_{2} \mathrm{O}_{2}$ (the highest concentration was $750 \mu \mathrm{M}$ ) (Fig. $3 \mathrm{~A}$ and $\mathrm{B}$ ). $\mathrm{H}_{2} \mathrm{O}_{2}$ was added to the cell culture repeatedly to identify the maximum change in the signal intensity during oxidation. Normally, the cells do not require any extra reductants to reduce biosensors similar to roKate. However, roKate was not reduced in the cytoplasm of HeLa Kyoto cells even when the cells were incubated with different reductants, including dithiothreitol, $\beta$ - mercaptoethanol, and tris(2-carboxyethyl) phosphine). The construct bearing no Grx1 at the N-terminus was inferior to the full-sized biosensor in terms of the reaction rate (Fig. 2A). This means that Grx1 has a key role in supporting the equilibrium between the intracellular glutathione pool and the redox-active cysteine residues of the sensor. The mutant without mKate2 cysteine residues did not change its fluorescence in the eukaryotic system.

In mammalian cells, roKate is oxidized irreversibly, meaning that the sensor can only report the oxidation dynamics of the glutathione pool and is unable to sense its reverse reduction.

\section{DISCUSSION}

We have developed a genetically encoded biosensor based on the red fluorescent protein mKate2. The biosensor is capable of reporting the redox state of the glutathione pool. The properties and design of roKate differ from those of a previously proposed rxRFP sensor [27] that was based on a circular permutated red fluorescent cpmApple protein. Circular permutants of fluorescent proteins are obtained by connecting (at the gene level) the "native" $\mathrm{N}$ - and C-termini to each other by a polypeptide linker sequence; the new $\mathrm{N}$ - and C-termini are formed in close proximity to a chromophore. The structure of a circular permutantis more conformationally flexible, affecting its spectral characteristics. In rxRFP, redox-active cysteine residues are located at the $\mathrm{N}$ - and $\mathrm{C}$-termini of the circular permutant, but the protein is not fused to Grx [27], i. e. 
endogenous Grx is needed to support the equilibrium between the redox state of the surrounding glutathione pool and the protein. Besides, chromophores of circular permutants are more susceptible to the environment in comparison with native proteins. This explains why the rxRFP biosensor is sensitive to physiological fluctuations of $\mathrm{pH}$.

Another member of the red fluorescent protein-based biosensor family specialized in monitoring the 2GSH/GSSG ratio is called Grx1-roCherry. It has a classic structure composed of a mCherry protein containing a pair of redoxactive cysteines and Grx1 fused to the protein by a polypeptide linker sequence. Its redox potential $(-311 \mathrm{mV})$ is different from roKate's; it also differs from our biosensor in the ability to be reversibly reduced in mammalian cells [28].

Red fluorescent proteins are more convenient when it comes to in vivo experiments in living systems. They can be used in parallel with green sensors for multiparameter microscopy. This approach yields a wealth of valuable information since it allows researchers to monitor the behavior of several parameters within one biological system or one parameter in different cell compartments [29].

The reason why the oxidized roKate sensor does not get reduced in mammalian cells is unknown. But the protein can be used as a "memory sensor" that reports the moment of oxidation in living cells or tissue. This could be convenient when the time between the manipulations with the biological object and fluorescence measurements is quite substantial, as is the case with long sample preparation. The time required for sample preparation can be sufficient for the cells to restore their glutathione pool, thereby skewing the results of the experiment. In mammalian cells, roKate gets irreversibly oxidized allowing us to detect glutathione oxidation. Besides, the biosensor can be used to monitor the oxidation dynamics of the intracellular glutathione pool in real time.

\section{CONCLUSIONS}

We have designed a new genetically encoded red-protein based biosensor, which we called roKate, capable of reporting the redox state of the glutathione pool. The biosensor can be used to study redox reactions related to the fluctuations in the $2 \mathrm{GSH} / \mathrm{GSSG}$ ratio in bacterial cells. In mammalian cells, roKate gets irreversibly oxidized and therefore can be employed as a "memory sensor" reporting the oxidation dynamics of the glutathione pool.

\section{References}

1. Lushchak VI. Glutathione homeostasis and functions: potential targets for medical interventions. J Amino Acids. 2012; 2012: 736837.

2. Couto N, Wood J, Barber J. The role of glutathione reductase and related enzymes on cellular redox homoeostasis network. Free Radic Biol Med. 2016; (95): 27-42.

3. Nagy P. Kinetics and mechanisms of thiol-disulfide exchange covering direct substitution and thiol oxidation-mediated pathways. Antioxid Redox Signal. 2013; 18 (13): 1623-41.

4. Bekris LM, Shephard C, Janer M, Graham J, McNeney B, Shin J, Zarghami M, Griffith W, Farin F, Kavanagh TJ, Lernmark A. Glutamate cysteine ligase catalytic subunit promoter polymorphisms and associations with type 1 diabetes age-at-onset and GAD65 autoantibody levels. Exp Clin Endocrinol Diabetes. 2007; 115 (4): 221-28.

5. Polonikov AV, Ivanov VP, Solodilova MA, Khoroshaya IV, Kozhuhov MA Panfilov VI. The relationship between polymorphisms in the glutamate cysteine ligase gene and asthma susceptibility. Respir Med. 2007; 101 (11): 2422-4.

6. Tosic M, Ott J, Barral S, Bovet P, Deppen P, Gheorghita F, Matthey ML, Parnas J, Preisig M, Saraga M, Solida A, Timm S, Wang AG, Werge T, Cuenod M, Do KQ. Schizophrenia and oxidative stress: glutamate cysteine ligase modifier as a susceptibility gene. Am J Hum Genet. 2006; 79 (3): 586-92.

7. Ramos PS, Oates JC, Kamen DL, Williams AH, Gaffney PM, Kelly $\mathrm{JA}$, et al. Variable association of reactive intermediate genes with systemic lupus erythematosus in populations with different African ancestry. J Rheumatol. 2013; 40 (6): 842-9.

8. Kamerbeek NM, van Zwieten R, de Boer M, Morren G, Vuil H, Bannink $\mathrm{N}$, et al. Molecular basis of glutathione reductase deficiency in human blood cells. Blood. 2007; 109 (8): 3560-6.

9. Backos DS, Franklin CC, Reigan P. The role of glutathione in brain tumor drug resistance. Biochem Pharmacol. 2012; 83 (8): 1005-12.

10. Huh YJ, Kim JM, Kim H, Song H, So H, Lee SY, et al. Regulation of osteoclast differentiation by the redox-dependent modulation of nuclear import of transcription factors. Cell Death Differ. 2006; 13 (7): 1138-46

11. Kim JM, Kim H, Kwon SB, Lee SY, Chung SC, Jeong DW, et al. Intracellular glutathione status regulates mouse bone marrow monocyte-derived macrophage differentiation and phagocytic activity. Biochem Biophys Res Commun. 2004; 325 (1): 101-8.
12. Suthanthiran M, Anderson ME, Sharma VK, Meister A. Glutathione regulates activation-dependent DNA synthesis in highly purified normal human T lymphocytes stimulated via the CD2 and CD3 antigens. Proc Natl Acad Sci USA. 1990; 87 (9): 3343-7.

13. Garcia-Ruiz C, Fernandez-Checa JC. Redox regulation of hepatocyte apoptosis. J Gastroenterol Hepatol. 2007; (22 Suppl 1): 38-42.

14. Ballatori N, Krance SM, Notenboom S, Shi S, Tieu K, Hammond CL. Glutathione dysregulation and the etiology and progression of human diseases. Biol Chem. 2009; 390 (3): 191-214.

15. Armstrong RN. Glutathione S-transferases: reaction mechanism, structure, and function. Chem Res Toxicol. 1991; 4 (2): 131-40.

16. Sedlak J, Lindsay $\mathrm{RH}$. Estimation of total, protein-bound, and nonprotein sulfhydryl groups in tissue with Ellman's reagent. Anal Biochem. 1968; 25 (1): 192-205.

17. Jiang X, Yu Y, Chen J, Zhao M, Chen H, Song X, et al. Quantitative imaging of glutathione in live cells using a reversible reactionbased ratiometric fluorescent probe. ACS Chem Biol. 2015; 10 (3): 864-74

18. Jiang X, Chen J, Bajic A, Zhang C, Song X, Carroll SL, et al. Quantitative real-time imaging of glutathione. Nat Commun. 2017; (8): 16087.

19. Ostergaard H, Henriksen A, Hansen FG, Winther JR. Shedding light on disulfide bond formation: engineering a redox switch in green fluorescent protein. EMBO J. 2001; 20 (21): 5853-62.

20. Hanson GT, Aggeler R, Oglesbee D, Cannon M, Capaldi RA, Tsien RY, et al. Investigating mitochondrial redox potential with redoxsensitive green fluorescent protein indicators. J Biol Chem. 2004; 279 (13): 13044-53.

21. Dooley CT, Dore TM, Hanson GT, Jackson WC, Remington SJ, Tsien RY. Imaging dynamic redox changes in mammalian cells with green fluorescent protein indicators. J Biol Chem. 2004; 279 (21): 22284-93.

22. Schwarzlander M, Dick TP, Meyer AJ, Morgan B. Dissecting Redox Biology Using Fluorescent Protein Sensors. Antioxid Redox Signal. 2016; 24 (13): 680-712.

23. Shcherbo D, Murphy CS, Ermakova GV, Solovieva EA, Chepurnykh TV, Shcheglov AS, et al. Far-red fluorescent tags for protein imaging in living tissues. Biochem J. 2009; 418 (3): 567-74.

24. Available from: www.clontech.com, протокол № РТ3393-1.

25. Bjornberg $\mathrm{O}$, Ostergaard $\mathrm{H}$, Winther JR. Mechanistic insight provided by glutaredoxin within a fusion to redox-sensitive yellow 
fluorescent protein. Biochemistry. 2006; 45 (7): 2362-71.

26. Gutscher M, Pauleau AL, Marty L, Brach T, Wabnitz GH, Samstag Y, et al. Real-time imaging of the intracellular glutathione redox potential. Nat Methods. 2008; 5 (6): 553-9.

27. Fan $Y$, Chen Z, Ai HW. Monitoring redox dynamics in living cells with a redox-sensitive red fluorescent protein. Anal Chem. 2015; 87 (5): 2802-10.

\section{Литература}

1. Lushchak VI. Glutathione homeostasis and functions: potentia targets for medical interventions. J Amino Acids. 2012; 2012: 736837.

2. Couto N, Wood J, Barber J. The role of glutathione reductase and related enzymes on cellular redox homoeostasis network. Free Radic Biol Med. 2016; (95): 27-42.

3. Nagy P. Kinetics and mechanisms of thiol-disulfide exchange covering direct substitution and thiol oxidation-mediated pathways. Antioxid Redox Signal. 2013; 18 (13): 1623-41.

4. Bekris LM, Shephard C, Janer M, Graham J, McNeney B, Shin J, Zarghami M, Griffith W, Farin F, Kavanagh TJ, Lernmark A. Glutamate cysteine ligase catalytic subunit promoter polymorphisms and associations with type 1 diabetes age-at-onset and GAD65 autoantibody levels. Exp Clin Endocrinol Diabetes. 2007; 115 (4): 221-28.

5. Polonikov AV, Ivanov VP, Solodilova MA, Khoroshaya IV, Kozhuhov MA, Panfilov VI. The relationship between polymorphisms in the glutamate cysteine ligase gene and asthma susceptibility. Respir Med. 2007; 101 (11): 2422-4.

6. Tosic M, Ott J, Barral S, Bovet P, Deppen P, Gheorghita F, Matthey ML, Parnas J, Preisig M, Saraga M, Solida A, Timm S, Wang AG, Werge T, Cuenod M, Do KQ. Schizophrenia and oxidative stress: glutamate cysteine ligase modifier as a susceptibility gene. Am J Hum Genet. 2006; 79 (3): 586-92.

7. Ramos PS, Oates JC, Kamen DL, Williams AH, Gaffney PM, Kelly $\mathrm{JA}$, et al. Variable association of reactive intermediate genes with systemic lupus erythematosus in populations with different African ancestry. J Rheumatol. 2013; 40 (6): 842-9.

8. Kamerbeek NM, van Zwieten R, de Boer M, Morren G, Vuil H, Bannink N, et al. Molecular basis of glutathione reductase deficiency in human blood cells. Blood. 2007; 109 (8): 3560-6.

9. Backos DS, Franklin CC, Reigan P. The role of glutathione in brain tumor drug resistance. Biochem Pharmacol. 2012; 83 (8): 1005-12.

10. Huh YJ, Kim JM, Kim H, Song H, So H, Lee SY, et al. Regulation of osteoclast differentiation by the redox-dependent modulation of nuclear import of transcription factors. Cell Death Differ. 2006; 13 (7): 1138-46.

11. Kim JM, Kim H, Kwon SB, Lee SY, Chung SC, Jeong DW, et al. Intracellular glutathione status regulates mouse bone marrow monocyte-derived macrophage differentiation and phagocytic activity. Biochem Biophys Res Commun. 2004; 325 (1): 101-8.

12. Suthanthiran M, Anderson ME, Sharma VK, Meister A. Glutathione regulates activation-dependent DNA synthesis in highly purified normal human $T$ lymphocytes stimulated via the CD2 and CD3 antigens. Proc Natl Acad Sci USA. 1990; 87 (9): 3343-7.

13. Garcia-Ruiz C, Fernandez-Checa JC. Redox regulation of hepatocyte apoptosis. J Gastroenterol Hepatol. 2007; (22 Suppl 1): 38-42.

14. Ballatori N, Krance SM, Notenboom S, Shi S, Tieu K, Hammond CL.
28. Shokhina AG, Kostyuk Al, Ermakova YG, Panova AS, Staroverov DB, Egorov ES, et al. Red fluorescent redox-sensitive biosensor Grx1roCherry. Redox Biol. 2019; (21): 101071.

29. Kostyuk AI, Panova AS, Bilan DS, Belousov W. Redox biosensors in a context of multiparameter imaging. Free Radic Biol Med. 2018; (128): 23-39.

Glutathione dysregulation and the etiology and progression of human diseases. Biol Chem. 2009; 390 (3): 191-214.

15. Armstrong RN. Glutathione S-transferases: reaction mechanism, structure, and function. Chem Res Toxicol. 1991; 4 (2): 131-40.

16. Sedlak J, Lindsay RH. Estimation of total, protein-bound, and nonprotein sulfhydryl groups in tissue with Ellman's reagent. Anal Biochem. 1968; 25 (1): 192-205.

17. Jiang X, Yu Y, Chen J, Zhao M, Chen H, Song X, et al. Quantitative imaging of glutathione in live cells using a reversible reactionbased ratiometric fluorescent probe. ACS Chem Biol. 2015; 10 (3): 864-74.

18. Jiang X, Chen J, Bajic A, Zhang C, Song X, Carroll SL, et al. Quantitative real-time imaging of glutathione. Nat Commun. 2017; (8): 16087.

19. Ostergaard H, Henriksen A, Hansen FG, Winther JR. Shedding light on disulfide bond formation: engineering a redox switch in green fluorescent protein. EMBO J. 2001; 20 (21): 5853-62.

20. Hanson GT, AggelerR, Oglesbee D, Cannon M, CapaldiRA, Tsien RY, et al. Investigating mitochondrial redox potential with redoxsensitive green fluorescent protein indicators. J Biol Chem. 2004; 279 (13): 13044-53.

21. Dooley CT, Dore TM, Hanson GT, Jackson WC, Remington SJ, Tsien RY. Imaging dynamic redox changes in mammalian cells with green fluorescent protein indicators. J Biol Chem. 2004; 279 (21): 22284-93.

22. Schwarzlander M, Dick TP, Meyer AJ, Morgan B. Dissecting Redox Biology Using Fluorescent Protein Sensors. Antioxid Redox Signal. 2016; 24 (13): 680-712.

23. Shcherbo D, Murphy CS, Ermakova GV, Solovieva EA, Chepurnykh TV, Shcheglov AS, et al. Far-red fluorescent tags for protein imaging in living tissues. Biochem J. 2009; 418 (3): 567-74.

24. Доступно по ссылке: www.clontech.com, протокол № РТЗ393-1.

25. Bjornberg O, Ostergaard H, Winther JR. Mechanistic insight provided by glutaredoxin within a fusion to redox-sensitive yellow fluorescent protein. Biochemistry. 2006; 45 (7): 2362-71.

26. Gutscher M, Pauleau AL, Marty L, Brach T, Wabnitz GH, Samstag Y, et al. Real-time imaging of the intracellular glutathione redox potential. Nat Methods. 2008; 5 (6): 553-9.

27. Fan $\mathrm{Y}$, Chen Z, Ai HW. Monitoring redox dynamics in living cells with a redox-sensitive red fluorescent protein. Anal Chem. 2015; 87 (5): 2802-10.

28. Shokhina AG, Kostyuk Al, Ermakova YG, Panova AS, Staroverov DB, Egorov ES, et al. Red fluorescent redox-sensitive biosensor Grx1roCherry. Redox Biol. 2019; (21): 101071.

29. Kostyuk Al, Panova AS, Bilan DS, Belousov W. Redox biosensors in a context of multiparameter imaging. Free Radic Biol Med. 2018; (128): 23-39. 